\title{
A AGENDA AMBIENTAL PÚBLICA: BARREIRAS PARA A ARTICULAÇÃO ENTRE CRITÉRIOS DE SUSTENTABILIDADE E AS NOVAS DIRETRIZES DA ADMINISTRAÇÃO PÚBLICA FEDERAL BRASILEIRA
}

\author{
Maria Gracinda Carvalho Teixeira \\ gracinda@uol.com.br \\ Universidade Federal Rural do Rio de Janeiro - Seropédica, RJ/Brasil \\ Luís Peres Azevedo \\ luispazevedo@yahoo.com.br \\ Universidade Federal de Minas Gerais - Belo Horizonte, MG/Brasil
}

\begin{abstract}
Recebido em 23/01/2012
Aprovado em 04/01/2013

Disponibilizado em 01/04/2013

Avaliado pelo sistema double blind review

Revista Eletrônica de Administração

Editor: Luís Felipe Nascimento

ISSN 1413-2311 (versão on-line)

Editada pela Escola de Administração da Universidade Federal do Rio Grande do Sul.

Periodicidade: Quadrimestral

Sistema requerido: Adobe Acrobat Reader.
\end{abstract}

\section{RESUMO}

A pesquisa tem como objetivo analisar a Instrução Normativa N01/2010 e suas implicações práticas, como novo instrumento de política pública o qual determina condições para viabilizar a agenda ambiental da gestão pública emanadas do Ministério de Orçamento, Planejamento e Gestão. Esta dispõe sobre os critérios de sustentabilidade ambiental na aquisição de bens, contratação de serviços ou obras pela administração pública federal. Assim supõe-se que haja uma necessidade de apreensão de novas formas de diálogo entre o público e o privado, o Estado e a sociedade face às mudanças institucionais postas à atual gestão pública e implícita na norma. Entretanto apresenta-se como problema de pesquisa o seguinte questionamento: quais fatores estariam causando o não alinhamento dos critérios de sustentabilidade ambiental exigidos à administração pública federal diante da situação em que se encontram as organizações parceiras contratadas, de modo a promover tal sustentabilidade? Realizou-se um estudo qualitativo, de natureza exploratória, abarcando pesquisa bibliográfica, documental e de campo. Esta última envolvendo gestores públicos federais que atuam em processos de licitação, em elaboração de projetos de obras e de fiscalização da construção das novas edificações públicas. Os resultados da pesquisa confirmam a suposição do estudo e apresentam as principais barreiras para a efetividade da norma sinalizando que sem uma maior articulação dos órgãos ambientais às novas diretrizes da administração pública federal e com claras responsabilizações quanto à norma em foco, estará comprometido o designo ambiental a que se propõe a nova legislação.

Palavras-chave: Agenda Ambiental; Política Pública; Instrução Normativa N01/2010; Serviços Públicos Ambientais. 
A agenda ambiental pública: barreiras para a articulação entre critérios de sustentabilidade e as novas diretrizes da administração pública federal brasileira

\title{
THE PUBLIC ENVIRONMENTAL AGENDA: BARRIERS TO THE ARTICULATION BETWEEN CRITERIA FOR SUSTAINABILITY AND THE NEW GUIDELINES OF THE BRAZILIAN CENTRAL GOVERNMENT ADMINISTRATION
}

\begin{abstract}
The research aims at studying Normative Instruction N01/2010 and its practical implications as a new instrument for public policies which sets conditions to enable the environmental agenda in the public administration as issued by the Brazilian Department of Budget, Planning and Administration. It provides on the criteria for environmental sustainability in the acquisition of goods, contracting of services or work by the Federal Government administration. Thus, it is supposed that there is a need to apprehend new forms of dialogue between the public and private realms, the State and society, given the institutional changes faced by the present public administration and implied in the norm. However, the research problem to be answered is the following: which factors would be causing the absence of alignment between the criteria for environmental sustainability required from the federal public administration, to the situation the partner contracted organizations are in, so to promote such sustainability? A qualitative study was made, of an exploratory kind, entailing bibliographical, document and field research. Interviews were conducted in the latter with the public administrators involved in bidding procedures, as well as in the production of work projects and inspection of the construction of the new public buildings. The results from the research confirm the supposition of the study and present the main barriers for the affectivity of the norm pointing out that without a major articulation of the environmental bodies to the new guidelines of the federal public administration, with a clear acceptance of the responsibilities related to the norm, the environmental design, as proposed by the new legislations may find itself jeopardized.
\end{abstract}

Keywords: Environmental Agenda; Public Policy; Normative Instruction N01/2010; Public Environmental Services.

\section{INTRODUÇÃO}

Este trabalho tem como objetivo analisar a Instrução Normativa N01/2010 e suas implicações práticas como novo instrumento de política pública o qual determina condições para viabilizar a agenda ambiental da gestão pública emanadas do Ministério de Orçamento, Planejamento e Gestão (MOPG). Assim, focalizam-se os impasses para a internalização desse instrumento na gestão pública. A referida instrução normativa, publicada em Diário Oficial da União, dispõe sobre os critérios de sustentabilidade ambiental nos processos de extração e fabricação de produtos, na aquisição de bens e contratação de serviços ou obras pela administração pública federal (BRASIL/MOPG, 2010). A pesquisa, portanto, discute os impactos da criação e implantação desse instrumento de gestão assim como os avanços e 
entraves resultantes dessa nova situação percebidos pelos gestores públicos envolvidos, encarregados de executar a instrução normativa.

A presente dinâmica insere o setor público no centro do debate do desenvolvimento sustentável e no papel de estimular uma readequação do mercado no que diz respeito aos serviços públicos impondo exigências às instituições públicas afetas à referida Instrução Normativa e às empresas parceiras, em particular, as fornecedoras que, por sua vez, passarão a apresentar produtos qualificados e a ofertarem serviços considerados ambientalmente sustentáveis. Esta situação se constitui um desafio não somente para as instituições públicas, mas também para todas as organizações privadas com as quais estabelecem parceria, pois a implementação da Instrução Normativa N01/2010 implica em uma mudança de paradigma que exige rupturas com valorações do passado incompatíveis com padrões sociais, econômicos e ambientais atuais e futuros mais duráveis.

Com efeito, a Instrução Normativa N01/2010 pressupõe que as edificações públicas sejam realizadas com base na economia de baixo carbono e, consequentemente de acordo com um amplo leque de exigências que garantam entre outros requisitos, a diminuição do consumo de energia e água, além da utilização de tecnologias e materiais que reduzam o impacto ambiental dessas edificações. Assim, este novo instrumento conduz a consecução do empreendimento público de maneira a torná-lo sujeito às normas do Conselho Nacional do Meio Ambiente (CONAMA). Deste modo, é necessário compreender como os órgãos responsáveis pelo licenciamento, como o Instituto Brasileiro do Meio Ambiente e dos Recursos Naturais (IBAMA) têm atuado na legislação ambiental e descentralizado sua atuação através de várias leis emanadas de órgãos públicos federais como o ministério em questão. Lembra Barbieri (2007) que a Lei nº 6.938/81, que definiu a Política Nacional de Meio Ambiente (PNMA), lançou as bases dos instrumentos de licenciamento ambiental, definiu as etapas do licenciamento além da sua obrigatoriedade. No mesmo sentido a Resolução CONAMA no $237 / 97$ expandiu a definição dessas etapas e incluiu o grau de competência dos órgãos ambientais quanto ao licenciamento.

No Brasil, segundo Teixeira e Azevedo (2009), emergiram e consolidaram-se importantes movimentos e mudanças no campo da proteção ao meio ambiente, ressaltando-se principalmente: a obrigatoriedade de estudos de impacto ambiental em empreendimentos potencialmente poluidores; o fortalecimento do quadro legal e do aparelho institucional de proteção do meio ambiente; maior eficácia e presença de órgãos públicos como o Ministério Público e o Poder Judiciário e das organizações civis, no licenciamento e na fiscalização de 
A agenda ambiental pública: barreiras para a articulação entre critérios de sustentabilidade e as novas diretrizes da administração pública federal brasileira

empreendimentos e embargos frequentes de estudos, instalações e operação de empreendimentos por ação judicial ou mobilização de segmentos da sociedade. No entanto, apesar da emissão da agenda ambiental na administração pública em 2001, o setor público só recentemente passou a se preocupar com as contratações que incluíssem aspectos de sustentabilidade ambiental, em função da Instrução Normativa N01/2010. Órgãos de controle como o Tribunal de Contas da União (TCU), passaram a auditar as compras e obras públicas, visando verificar a inclusão dos critérios da referida agenda nas licitações públicas.

A agenda ambiental na administração pública foi criada para servir de instrumento de sensibilização, acreditando-se que encontraria eco nos diversos segmentos e instâncias do poder público e seus parceiros e revelaria lideranças locais comprometidas com a difusão dos conceitos e das práticas nela preconizados, assim como foi idealizada. Dessa forma, um dos objetivos da agenda foi construir uma cultura institucional fundamentada na excelência da gestão ambiental de modo que viesse contribuir para o fortalecimento das diretrizes para o desenvolvimento sustentável do país no tocante às obras públicas.

A partir desse contexto a pesquisa expõe de um modo geral, os problemas que ocorrem no processo de internalização das políticas ambientais pelos órgãos públicos brasileiros, tomando como base empírica do estudo o impacto da referida norma no serviço público federal no qual seus gestores e corpo técnico começam a se preparar para a introdução dos critérios de sustentabilidade ambiental no projeto, licitação e fiscalização de novas edificações públicas. Essas edificações fazem parte do programa de governo federal, o Plano de Expansão das Agências (PEX), da autarquia Instituto Nacional do Seguro Social (INSS), do Ministério da Previdência Social, o qual integra o Programa de Aceleração do Crescimento (PAC) do governo federal. O PEX é responsável por viabilizar a construção de 1100 novas agências no país as quais terão que se adequar às novas posturas públicas ambientais, principalmente as contempladas na Instrução Normativa N01/2010. Portanto, para estudar os impactos desta norma privilegiou-se a dinâmica do serviço público federal no tocante à implantação da mesma.

Considerando esse novo cenário e a inserção de novos atores, o estudo supõe que há uma necessidade de apreensão de novas formas de diálogo entre o público e o privado, o Estado e a sociedade face às mudanças institucionais postas à atual gestão pública e implícita na norma em questão, o que deverá se fazer presente no processo de sua implementação. Entretanto apresenta-se como problema de pesquisa o seguinte questionamento: quais fatores estariam causando o não alinhamento dos critérios de sustentabilidade ambiental exigidos à 
administração pública federal diante da situação em que se encontram as organizações parceiras contratadas, de modo a promover tal sustentabilidade? Ao procurar responder a referida indagação, a pesquisa sinalizará as barreiras para a efetividade da legislação em foco.

O trabalho está organizado em cinco seções. Na primeira que trata da introdução em questão, dá-se a contextualização do estudo e a problematização do objeto a Instrução Normativa N01/2010 e define-se o objetivo do trabalho. Na segunda seção discorre-se sobre os procedimentos metodológicos da pesquisa. A terceira seção apresenta a fundamentação teórica da pesquisa, dividida em três partes: na primeira, discute-se sobre o que traz de inovador a agenda ambiental da gestão pública brasileira; na segunda apresenta-se uma reflexão sobre as mudanças institucionais e a internalização dos instrumentos de política ambiental nas organizações e na terceira parte, se discute sobre as edificações públicas e o mercado de serviços ambientais. A quarta seção do artigo é construída com base na pesquisa de campo na qual se dá o registro da análise empírica nos dois momentos da pesquisa, e por último, na quinta seção, apresentam-se as conclusões do trabalho, seguidas do mapeamento comparativo da Instrução Normativa N01/2010 de acordo com a visão dos entrevistados. Por último expõem-se as referências bibliográficas.

\section{METODOLOGIA}

Os procedimentos metodológicos da pesquisa constituíram-se de três estágios interdependentes.

a) Primeiro Estágio

Procedeu-se o levantamento e o aprofundamento da revisão da literatura especializada nacional e estrangeira por meio das quais foram sistematizadas informações publicadas em livros, periódicos, teses e dissertações e registros encontrados em sites relevantes a respeito do tema.

Definiu-se o estudo como de natureza qualitativa, de caráter descritivo e exploratório. Esse estágio representou a etapa exploratória da pesquisa, em que se buscou levantar informações sobre o objeto de estudo, a Instrução Normativa N01/2010, traçar os objetivos e formular o problema de pesquisa, delimitando o campo de trabalho e delineando-se dois momentos da pesquisa: o primeiro, em que se implantou a norma e, portanto o foco principal desse momento foi compreender o impacto da criação de um novo instrumento de gestão de política pública que implicaria em mudança de paradigma na condução de novos projetos de edificações públicas. Já o segundo momento foi o mapeamento dos entraves e avanços 
A agenda ambiental pública: barreiras para a articulação entre critérios de sustentabilidade e as novas diretrizes da administração pública federal brasileira

passíveis de avaliação da referida Instrução Normativa após um ano de implantada e considerando seus desdobramentos. Justifica-se a tipologia de pesquisa com base em Vergara (2006, p.47) segundo a qual, a investigação do tipo exploratório "é realizada em área na qual há pouco conhecimento acumulado e sistematizado"; a descritiva "expõe características de determinado fenômeno" e embora não tenha o compromisso em explicar os fenômenos que descreve, "serve de base para tal explicação" e a de campo "é investigação empírica realizada no local onde ocorreu o fenômeno ou que dispõe de elementos para explicá-lo”.

A pesquisa e análise de conteúdo documental foram realizadas nesse estágio do estudo. Entre as fontes documentais analisadas destacam-se: (i) a Instrução Normativa N01/2010; (ii) documentos acessados na obra "A Auditoria de Aspectos Ambientais nas Obras Públicas" (2002); (iii) Lei de Licitações n 8.666/93; (iv) a Agenda Ambiental na Administração Pública, documento gerado em 2001 pelo Ministério do Meio Ambiente, importante balizamento para os critérios de sustentabilidade a serem adotados pelos órgãos da administração pública.

b) Segundo Estágio

Realizou-se neste estágio a construção do desenho teórico-empírico da pesquisa o qual configura o conjunto de relações que se pretendeu investigar, revelando uma situação específica de indicadores ou categorias e suas inter-relações, assim como as articulações teóricas com o campo empírico.

Nesse sentido, definiu-se como principais elementos constitutivos do desenho: a identificação da Instrução Normativa N01/2010 e do arcabouço legal que a ampara, assim como os aspectos conceituais relacionados à política ambiental pública, à agenda ambiental nos órgãos públicos, à institucionalização da Instrução Normativa e à questão dos mercados de serviços ambientais que seriam estimulados pelo Estado através da norma. Alguns desses elementos foram internalizados nas questões formuladas aos respondentes, norteando o levantamento do corpus empírico (Orlandi, 1999).

\section{b) Terceiro Estágio}

Constitui-se como atividade nesse estágio da pesquisa, o trabalho de campo que se baseou em fontes orais. Para tal, elaborou-se um roteiro semiestruturado de questões para a entrevista, as quais foram respondidas por e-mail em função das dificuldades de deslocamento a determinadas cidades da região sudeste. As questões procuraram enfocar os aspectos mais importantes para a caracterização do objeto, tendo sido analisada e interpretada a verbalização dos sujeitos cujo resultado da análise foi apresentado na forma de discussão seguida de um 
mapeamento comparativo, envolvendo os dois momentos da pesquisa como acima descritos, conforme mostra o Quadro 1 ao final do artigo.

Foram privilegiados na pesquisa gestores públicos da esfera federal envolvidos com a implantação da Instrução Normativa N01/2010. Esses gestores são servidores de nível superior, engenheiros e arquitetos com larga experiência acadêmica e profissional em gestão pública, responsáveis pelo planejamento, especificações técnicas e fiscalização de obras de novas agências do INSS integrantes do PEX na Superintendência Regional Sudeste, nos Estados de Minas Gerais, Espírito Santo e Rio de Janeiro. Os profissionais selecionados também são envolvidos em licitações, projetos e fiscalização da construção das novas agências. Entre vários gestores localizados, apenas um grupo de sete gestores se dispôs a participar da pesquisa, respondendo as questões previamente elaboradas. Por se tratar de uma instrução normativa recente e de conteúdo polêmico, isso se tornou um fator crítico na escolha dos respondentes e talvez seja uma razão quanto à recusa de alguns contatados a responder as questões da pesquisa, além da falta de disponibilidade justificada pelos mesmos. O número de respondentes, portanto, se constitui um fator limitante do presente estudo. Por solicitação dos sujeitos, adotou-se o critério ético da confidencialidade dos seus nomes tendo sido substituídos por números.

$\mathrm{Na}$ abordagem empírica, utilizou-se uma vertente do método fenomenológico interpretativo na análise dos dados sugerida por Arce e Long (1992) e Giddens (1984) segundo a qual se procede a escolha dos atores e a análise do conteúdo do discurso daqueles que estão envolvidos com o assunto investigado. Consequentemente atribui-se conhecimento a estes sujeitos, pela sua capacidade organizativa e de articulação e não somente por estarem em esferas de decisão. Assim, conforme apontam os autores, valorizam-se as estratégias dos atores sociais e seus significados considerados relevantes para o entendimento da problemática em estudo. Nessa vertente compartilhada por Orlandi (1999) o pesquisador está mais voltado para os efeitos da comunicação e seu sentido e não tanto para a forma e conteúdo e a interpretação sempre será passível de equívoco, posto que a pesquisa ancora-se na verbalização dos sujeitos e de acordo com suas razões; as realidades são plurais e o conhecimento inacabado.

O primeiro momento da pesquisa de campo ocorreu entre maio e junho de 2010 e o segundo momento, entre fevereiro e março de 2011, um ano depois de implantada a Instrução Normativa com a participação dos mesmos gestores. Portanto, do ponto de vista metodológico 
A agenda ambiental pública: barreiras para a articulação entre critérios de sustentabilidade e as novas diretrizes da administração pública federal brasileira

e de alcance dos resultados da pesquisa, os dois momentos do estudo são interdependentes e complementares.

\section{FUNDAMENTAÇÃO TEÓRICA}

\subsection{A agenda ambiental da gestão pública: o que há de novo?}

A literatura disponível sobre a relação entre política ambiental pública e a gestão ambiental nos órgãos públicos ainda é escassa, pois apesar de existirem referências sobre normas, a instrumentalização legal concernente é recente e, portanto, não há ainda pesquisas sobre a avaliação dos resultados da utilização dessa nova instrumentalização. Além disso, não se tem considerado quais são as condições existentes nos órgãos públicos para internalizarem mudanças institucionais que dizem respeito à política pública ambiental, a qual envolve questões estratégicas como, por exemplo, o critério do menor custo instituído pela Lei $n^{\circ}$ 8.666/93, que deve passar a ser relativizado levando em conta a exigência normativa e padrões de sustentabilidade (BRASIL/MOPG, 2010), que requerem a construção de novos indicadores.

As diretrizes da agenda ambiental da administração pública (BRASIL/MMA, 2001), apontam que as demandas geradas nas três esferas de governo - federal, estadual e municipal, apresentam excessivo consumo de recursos naturais, razão que estaria levando o governo federal a assumir papel estratégico na indução de novos referenciais de produção e consumo, orientados para a sustentabilidade. No mesmo documento registra-se que cabe aos órgãos que compõem a administração pública, dar o primeiro passo em direção à implementação de políticas e mecanismos de redução do consumo de recursos naturais, diminuindo impactos ambientais em suas atividades, incentivando o combate ao desperdício e programas de práticas de reaproveitamento e reciclagem de materiais e o incentivo às certificações ambientais. Assim sintetizam-se no documento "Agenda Ambiental na Administração Pública", seus principais objetivos: (i) promover a reflexão sobre os problemas ambientais em todos os níveis da administração pública; (ii) estimular a adoção de atitudes e procedimentos que levem ao uso racional dos recursos naturais e dos bens públicos; (iii) reduzir a destinação inadequada de resíduos sólidos; (iv) estimular e promover mudanças de hábitos dos servidores públicos; e (v) reacender a ética e a autoestima dos servidores públicos (BRASIL/MMA, 2001).

A Instrução Normativa em estudo deixou o ano de 2010 marcado pela inserção de critérios ambientais nas licitações públicas brasileiras. Junto com a entrada da Lei Federal $n^{\circ}$

REAd I Porto Alegre - Edição 74 - N 1 - jan/abr 2013 - p. 139-164 
12.349, em vigor desde 19 de janeiro de 2010, ela representou um avanço acerca da antiga polêmica do crescimento nacional versus desenvolvimento sustentável, sendo dessa vez, travado no interior dos órgãos públicos. Os ganhos deste debate para os órgãos públicos, para a gestão pública e para a sociedade são apresentados por Fernandes (2010), segundo o qual é possível realizar no país uma compra pública ecologicamente correta. A Lei no 12.349/2010 alterou o artigo $3^{\circ}$ da Lei de Licitações $n^{\circ} 8.666 / 93$, trazendo em seu texto o aspecto particular das licitações sustentáveis como uma forma de viabilizar o desenvolvimento nacional sustentável no setor de serviços.

Considerada o grande marco regulatório das compras de serviços e obras no Governo Federal, a norma define em seu Artigo $1^{\circ}$ :

Nos termos do art. $3^{\circ}$ da Lei $\mathrm{n}^{\circ}$ 8.666, de 21 de junho de 1993, as especificações para a aquisição de bens, contratação de serviços e obras por parte dos órgãos e entidades da administração pública federal direta, autárquica e fundacional deverão conter critérios de sustentabilidade ambiental, considerando os processos de extração ou fabricação, utilização e descarte dos produtos e matérias-primas (BRASIL/MOPG, 2010).

Observa-se que a norma em foco lança o tema da sustentabilidade ambiental sinalizando as expectativas postas aos órgãos e entidades da administração pública federal nos processos acima descritos. Com a reformulação da Lei $n^{\circ} 8.666 / 93$ o seu art. $3^{\circ}$ passa a exigir que a licitação esteja condizente com a "promoção do desenvolvimento nacional sustentável", ou melhor, exige-se uma licitação sustentável conforme se lê a seguir:

A licitação destina-se a garantir a observância do princípio constitucional da isonomia, a seleção da proposta mais vantajosa para a administração e a promoção do desenvolvimento nacional sustentável e será processada e julgada em estrita conformidade com os princípios básicos da legalidade, da impessoalidade, da moralidade, da igualdade, da publicidade, da probidade administrativa, da vinculação ao instrumento convocatório, do julgamento objetivo e dos que lhe são correlatos (BRASIL/MOPG, 2010).

Com a ajuda de Pimentel, et al. (2010), compreende-se a licitação sustentável como sendo um procedimento administrativo que visa a satisfação do interesse público, respeitando a igualdade de condições entre os participantes, fazendo com que a administração pública REAd I Porto Alegre - Edição 74 - Nº 1 - jan/abr 2013 - p. 139-164 
A agenda ambiental pública: barreiras para a articulação entre critérios de sustentabilidade e as novas diretrizes da administração pública federal brasileira

adquira bens ou serviços ambientalmente corretos e levando em consideração todo o ciclo produtivo. Assim, com a entrada em vigor deste novo dispositivo legal, a licitação entra também em uma nova fase de execução, como determina a lei, ou seja, ela deverá ser processada e julgada, respeitando todos os princípios constitucionais inerentes à administração pública, de forma a promover o desenvolvimento nacional sustentável. E fica implícita na lei a responsabilidade dos gestores públicos de promover a sustentabilidade do projeto desde o início com a internalização dos critérios ambientais em suas compras e contratações (SANTOS, 2011).

Assim vimos que a regulamentação ambiental tem um lado normativo e outro informativo - traduz as necessidades de proteção ambiental em documentos específicos, sinalizando para os poluidores e os fornecedores de tecnologias ambientais o que está sendo demandado. Em estudo realizado por Araújo e Mendonça (2007), os autores mostram que a busca pela sustentabilidade ambiental nas organizações surge a partir dos processos de adequação das mesmas às normas internacionalmente reconhecidas, sem que se deixe de considerar os contextos locais específicos.

A Instrução Normativa, portanto apresenta-se como um instrumento crucial de mudança institucional cuja internalização pelos órgãos públicos vai depender de múltiplos fatores para que não se torne apenas mais um componente na agenda ambiental da administração pública, uma vez que a mudança de paradigma referida no trabalho pressupõe rupturas com velhas posturas do passado e gerando novas mudanças comportamentais compatíveis com padrões sociais, econômicos e ambientais mais duráveis, como já enfatizado, estimulados neste caso, pelas organizações públicas.

\subsection{Mudanças institucionais e a internalização dos instrumentos de política ambiental}

Tendo em vista as dimensões técnicas e político-institucionais que perpassam a Instrução Normativa N01/2010 em análise e que também são inerentes à política ambiental brasileira, achou-se pertinente esboçar nesse tópico a contribuição do enfoque institucional dos estudos organizacionais de uma vertente do chamado novo institucionalismo ou neoinstitucionalismo para se compreender o significado das mudanças institucionais que está embutido na nova instrumentalização e seu poder de promover padrões de sustentabilidade na gestão pública. Segundo Scott (1983) a perspectiva neoinstitucional abandona a concepção de um ambiente formado exclusivamente por recursos humanos, materiais e econômicos para destacar a presença de elementos culturais - valores, símbolos, mitos, sistema de crenças e REAd I Porto Alegre - Edição 74 - Nº 1 - jan/abr 2013 - p. 139-164 
programas profissionais. O neo-institucionalismo imprimiu novos elementos como os sociais, culturais e cognitivos que se apresentam tão poderosos quanto os aspectos econômicos dos ambientes organizacionais.

Peci (2006), entretanto argumenta que uma das limitações do novo institucionalismo, apesar de ampliado o seu entendimento das instituições e da sociedade, representado por Scott (1983), é que permanece tratando o ambiente técnico como distinto do ambiente institucional, ao distinguir as regras institucionalizadas dos comportamentos sociais predominantes.

Para entender como a sociedade cria relações sobre a aparente dicotomia posta pelo neo-institucionalismo entre ambiente técnico e ambiente institucional, sugere-se uma interface teórica com a contribuição de Nunes (1997), segundo o qual ocorre um processo de interferência política sobre a tecnocracia e o insulamento burocrático próprios de algumas instituições públicas o que pode afetar a consecução dos objetivos, seja em função da lentidão da burocracia e do processo de negociação ou da preservação do conteúdo racional da política pública.

Crubellate (2007) sugere que o processo institucional seja um processo em contínua transformação, formação e desconstrução, possuindo sempre um lado concreto e exterior e que dependa das relações travadas no cotidiano entre os atores, sendo estes também influenciados pelo o processo institucional. Ressalta, portanto, que "a correlação entre estruturas e ações organizacionais é circular" (CRUBELLATE, 2007, p. 217). Argumenta que, do mesmo modo que estruturas influenciam ações institucionais, também as forças do ambiente organizacional entram em processo de institucionalização. Dessa forma pressupõese que assim como as organizações incorporam mudanças ou constroem barreiras às mudanças institucionais, estas podem proporcionar um ambiente inovador que motivaria mudanças ou processos contrários, os de resistência à mudança, o que nos parece uma reflexão crucial para a compreensão da dinâmica relacionada à internalização da Instrução Normativa o que se verá adiante neste trabalho. Por outro lado, a reflexão acima ajuda a compreender também os impasses quanto à tomada de decisão concernente às questões ambientais envolvendo os órgãos públicos.

A discussão da norma traz à tona o tema das ações públicas que ganham vulto no país com o controle interno e externo na defesa do meio ambiente. Segundo Lima, (2009, p. 28-29) “a gestão ambiental pública, além do controle interno, exercido pelas auditorias internas e pela Controladoria Geral da União (CGU), experimenta também o controle externo, por intermédio do Tribunal de Conta da União (TCU), o controle social e o controle 
A agenda ambiental pública: barreiras para a articulação entre critérios de sustentabilidade e as novas diretrizes da administração pública federal brasileira

jurisdicional". Explica o autor que o controle social é efetivado mediante manifestações, participações em audiências públicas e conselhos e ainda por meio de denúncias ao TCU e ao Ministério Público. O controle jurisdicional, por sua vez, caracteriza-se pelo princípio da inércia dos órgãos julgadores, ou seja, eles só atuam se provocados por iniciativas como a proposição pelo Ministério Público de ações civis públicas por danos ao meio ambiente, assim como apontado pelo referido autor. Destaque-se que há um intercâmbio permanente de informações entre o controle interno e o TCU e que, com frequência, o TCU comunica ao Ministério Público indícios de irregularidades identificados em seus trabalhos de fiscalização para o competente exame e eventual ajuizamento de ações civis e penais. Também cabe mencionar que, pelo mecanismo dos Termos de Ajuste de Conduta (TAC), o Ministério Público influencia diretamente a gestão ambiental.

Há quem questione a Instrução Normativa expondo redundâncias e incoerências. É o caso de Ferreira (2010). Para o autor “o administrador público já está subordinado à obediência aos princípios da legalidade, impessoalidade, moralidade, publicidade e eficiência" (FERREIRA, 2010, p. 77), conforme a Constituição Federal. Nesta esfera de atuação, vale dizer, vinculada, o processo de licitação está legalmente contemplado, inclusive na discricionária (assim como as hipóteses de inexigibilidade e dispensa de licitação), pois de qualquer modo, o administrador público já era obrigado a fundamentar a justificativa para adoção de qualquer medida relativa à licitação, conforme argumenta o autor. Acresça-se a isto, a atual necessidade de "promoção do desenvolvimento nacional sustentável", conforme texto da Lei $\mathrm{n}^{\circ}$ 8.666/93, que, como argumenta o referido autor, é dever não só da esfera pública como da privada. Nesse sentido, contesta Ferreira que a adoção de critérios sustentáveis estabelecidos por instrumento normativo como é o caso da Instrução Normativa N01/2010, parece redundante e se sobrepõe ao princípio da legalidade, que em sua opinião, compete à União, por intermédio do processo legislativo. O referido autor também ressalta que o estímulo à internalização de critérios sustentáveis por decretos ou instruções normativas são assuntos polêmicos. Para ele, a "sustentabilidade não pode ser estimulada por decreto, como está ocorrendo, mas se pautar nas leis pertinentes a licitações e, principalmente, na Constituição Federal” (FERREIRA, 2010, p. 17-18). Polemiza ainda o autor que a exigência de certificação ambiental como documento de qualificação técnica "pode ocasionar efeito inverso de discriminação na participação de licitantes e infringência à própria Constituição Federal," acreditando o autor que pode haver demanda ao Poder Judiciário e que a urgência 
da utilização de critérios sustentáveis, doravante, não pode "atropelar" a legalidade administrativa.

A Constituição brasileira desempenha importante papel na proteção ambiental; o Estado tem sido o fomentador da legislação ambiental e isso é claramente enfatizado na Constituição no art. 225, in verbis:

Todos têm direito ao meio ambiente ecologicamente equilibrado, bem de uso comum do povo e essencial à sadia qualidade de vida, impondo-se ao Poder Público e à coletividade o dever de defendê-lo e preservá-lo para as presentes e futuras gerações (BRASIL/CONSTITUIÇÃO FEDERAL, 1988).

Com a criação da Política Nacional do Meio Ambiente, da Lei do Código Florestal, da Lei dos Crimes Ambientais entre outras legislações importantes, o Estado tem se mostrado um agente promotor e normatizador do meio ambiente. Entretanto, no papel de agente normatizador confere também ao Estado a responsabilidade pelo cumprimento das leis ambientais perante os fornecedores da administração pública, o que é pertinente à presente pesquisa. Nesse sentido, a inclusão da sustentabilidade nas políticas fiscais tributárias se apresenta como importante estratégia governamental para a menor degradação ambiental e já com respaldo da Constituição Federal. E considerando a situação brasileira, o TCU avança no sentido de apoiar a aplicação dos critérios ambientais nas aquisições públicas, desde que estes sejam inseridos de modo paulatino, segundo Santos (2011), visto que o mercado não está ainda adaptado à nova realidade de compras públicas sustentáveis como política governamental.

\subsection{As edificações públicas e o mercado de serviços ambientais}

A relação entre as edificações públicas e o mercado de serviços ambientais, por tratarse de assunto inovador ainda é escasso tanto na literatura nacional - principalmente, quanto na internacional. Entretanto registra-se a contribuição de abordagens afins tanto na literatura brasileira quanto na estrangeira que contempla a associação entre essas duas temáticas.

Destaca-se na literatura internacional o estudo de Farhar e Coburn (2008) sobre a responsabilidade e o novo papel da indústria de edificações industriais e residenciais na nova economia de baixo carbono e que este setor começa a apresentar novas posturas por força de 
A agenda ambiental pública: barreiras para a articulação entre critérios de sustentabilidade e as novas diretrizes da administração pública federal brasileira

pressão social e legal dos países visando contribuir para o alcance das metas de redução de gases de efeito estufa.

Parris (2007) localizou em seus estudos que desde os anos 1990 os Estados Unidos e Europa vêm orientando políticas sobre as construções sustentáveis conhecidas na literatura como os green buildings, porém com ênfase no setor privado. Segundo o referido autor, só recentemente essas políticas passam a ter um caráter público no sentido da sua internalização pelos governos federais passando a se constituir politica pública nessa esfera, com a criação de programas governamentais, legislação e serviços da administração pública elencando, por exemplo, nas experiências americana e canadense o Department of Energy's Building Technologies Program, o Environmental Protection Agency's Energy Star Rating Program, e o General Services Administration's Sustainable Design Program.

Já na Europa destaca-se o órgão Network of European Environmental and Sustainable Development Advisory Councils (EEAC) que, segundo O’Riordan (2009), representa o trabalho e o lobby de vários governos nacionais e órgãos consultivos da União Europeia visando um objetivo comum: adotar um conceito novo e mais sustentável de desenvolvimento que possa contemplar vários aspectos do planejamento e das economias e sociedades modernas contemplando governança, justiça social, orçamentos públicos, mercados ambientais, culturas, demografia, regionalismo, localismo, educação e aprendizagem.

No Canadá, o conceito de green building é regulado pelo Canadian Environmental Protection Act de 1999 (ENVIRONMENT CANADA, 2012). Esta lei norteia a participação dos cidadãos nos processos de proteção ambiental, nas audiências públicas e no monitoramento permanente.

Em documentos públicos do Reino Unido, várias diretrizes são definidas para as compras governamentais, inclusive exigindo dos fornecedores o estabelecimento de metas e critérios adotados pelo Governo (SUSTAINABLE DEVELOPMENT IN GOVERNMENT, 2012).

Nos Estados Unidos da América, o Council on Environmental Quality Executive Office of the President é o órgão responsável pelo National Environmental Policy Act (NEPA) e que regula as posturas públicas e privadas quanto ao meio ambiente (NEPA, 2012). Complementarmente o Fed Center (2012), através de suas "Ordens de Execução" orienta a compra de materiais ecologicamente corretos pelo Governo Federal, nos aspectos de eficiência energética, reciclabilidade, baixo consumo de água, de energia e inclusive levando em conta o ciclo de vida sustentável dos produtos. Quanto às construções com critérios de 
sustentabilidade, o Fed estabelece as premissas para construções por parte do governo e particulares (FED CENTER, 2012).

No Brasil, a Instrução Normativa N01/2010 pressupõe o envolvimento do Governo Federal como motivador de ações e certificações de sustentabilidade e responsabilidade social tanto na esfera pública quanto na privada, pois apesar do rígido controle estatal sobre setores de compras e obras públicas, a norma introduz um fator de indução de melhorias na sustentabilidade tanto no âmbito do mercado quanto dos órgãos públicos.

$\mathrm{Na}$ literatura brasileira, registram-se as contribuições de Santos (2002) sobre auditoria de aspectos ambientais nas obras públicas; o trabalho de Biderman et al. (2006), envolvendo pesquisas sobre compras públicas sustentáveis; o estudo de Ferreira (2009) sobre licitação sustentável; a pesquisa de Lima (2009) sobre o Tribunal de Contas e o controle externo da gestão ambiental e mais recentemente Fernandes (2010) publica seu estudo sobre compras públicas e questões ecológicas.

Estudo de Fearnside (1997) explica que o pagamento pelos serviços ambientais pode trazer a noção da ruptura com a racionalidade de curto prazo usualmente adotada nas ações humanas, dando lugar a uma racionalidade de longo prazo, mais apropriada, na visão do autor quando se pensa as questões ambientais. Powell e White (2001) explicam que no contexto das mudanças institucionais envolvendo o meio ambiente como, por exemplo, com o surgimento dos mercados de serviços ambientais, o que deve a Instrução Normativa estimular, estes são classificados de acordo com o nível e a intervenção governamental. A classificação que mais nos chamou atenção foi aquela onde estão situados os pagamentos realizados pelo setor público, assim considerado quando algum nível de governo ou uma instituição pública paga pelo serviço ambiental. Os recursos para essas operações vêm de distintas fontes entre elas, as de orçamentos gerais de governos nas suas diversas esferas. $\mathrm{O}$ fato de serem arranjos públicos não exime a negociação. Pelo contrário, intensas negociações que envolvem poderes públicos, empresas e outros stakeholders são necessárias para o estabelecimento desse tipo de mecanismo, o qual exige mudanças no aparelho regulador e novas capacitações gerenciais.

As contribuições da literatura internacional em Fearnside (1997), Heal (2000), Powell e White (2001) e O'Riordan (2009) e da literatura brasileira com Veiga Neto e May (2010), entre outros, todas elas voltadas direta ou indiretamente para os estudos sobre mercados para serviços ambientais, permitem uma interface teórica com o objeto da presente pesquisa, uma vez que eles situam a temática em um novo campo de estudo das políticas públicas que é o dos serviços públicos ambientais. O estudo se apropria do conceito de serviços ambientais 
A agenda ambiental pública: barreiras para a articulação entre critérios de sustentabilidade e as novas diretrizes da administração pública federal brasileira

apresentado por Heal (2000) segundo o qual são aqueles que responsáveis pela infraestrutura necessária para o estabelecimento das sociedades humanas.

Assim, corroborando o que afirma Biderman et al. (2006), acredita-se que o marco regulatório instituído durante o Fórum Mundial sobre Mudanças Climáticas em Johanesburgo em 2002 que ficou conhecido como o Plano de Implementação de Johanesburgo, capítulo III, denominado Mudando Padrões Insustentáveis de Consumo e Produção, tenha sido um fator de grande incentivo às autoridades lá presentes para incluir no planejamento do desenvolvimento nacional e local, e consequentemente, incrementar nos programas públicos das nações, a promoção de políticas que viessem resultar no desenvolvimento e difusão da produção de bens e serviços ambientais sustentáveis, envolvendo infraestrutura, desenvolvimento de negócios, licitação pública entre outras inciativas concernentes.

Como exposto, a pesquisa envolve o impacto da criação de um novo instrumento de gestão de política pública que implica em mudança de paradigma na condução de novos projetos de edificações públicas e considera avaliar seus desdobramentos como, por exemplo, as alterações da Lei de Licitações $n^{\circ} 8.666 / 93$, lei esta que se constituía, no primeiro momento da pesquisa como um paradoxo à própria Instrução Normativa N01/2010. O paradoxo se configurava na lógica dos green buildings ou edificações sustentáveis que segundos cálculos no Brasil, custam de 5 a $10 \%$ a mais na construção (GREEN BUILDING COUNCIL BRASIL, 2010), contrariando o princípio das compras públicas sustentáveis que visam o menor custo.

Contudo, o que não havia sido amplamente debatido pela sociedade e pelos implementadores da norma durante o período da pesquisa é que ao mesmo tempo em que no caso das compras públicas sustentáveis, os custos reduzidos de operação levariam ao retorno do capital investido, a Instrução Normativa carregaria consigo prerrogativas de durabilidade e o princípio da justiça intergeracional. A associação entre esses dois elementos compreendemos como a essência do desenvolvimento sustentável, pois sugere a garantia de um ambiente saudável às gerações futuras.

\section{APRESENTAÇÃO E ANÁLISE DA PESQUISA DE CAMPO}

Como visto na metodologia do trabalho, o roteiro das questões foi encaminhado por email aos gestores públicos envolvidos em licitações, projetos e fiscalização da construção de novas agências da previdência social brasileira, como parte do PAC. Após a análise e interpretação dos depoimentos, procedeu-se um mapeamento comparativo da percepção dos

REAd I Porto Alegre - Edição 74 - № 1 - jan/abr 2013 - p. 139-164 
entrevistados de modo a se ter uma visão do todo nas duas fases do estudo o que pode ser observado no Quadro 1. Os sujeitos foram esclarecidos sobre os objetivos da pesquisa e a necessidade de considerar o roteiro de questões apenas como um norte, tendo sido solicitado o detalhamento e extensão máxima possível das respostas. Manteve o cuidado de envolver os mesmos profissionais nas duas fases da pesquisa de modo a se obter melhores resultados quanto à avaliação dos entrevistados sobre a implantação da Instrução Normativa.

Como ressaltado na seção da metodologia da pesquisa, foi respeitado o princípio ético da confidencialidade, de modo que os nomes dos gestores foram substituídos por números, configurando-se, portanto em um grupo de sete gestores identificados como gestor 1, gestor 2, gestor 3 , gestor 4 , gestor 5 , gestor 6 e gestor 7 .

A primeira questão visa saber sobre o conhecimento pleno do entrevistado da legislação relativa a obras sustentáveis e sua relação com as premissas da Instrução Normativa. A análise dessa questão evidencia que na primeira fase da pesquisa os gestores não possuíam conhecimento amplo da legislação que obriga a inclusão de critérios de sustentabilidade nas obras públicas. A justificativa apresentada para esse desconhecimento foi o excesso de compromissos de trabalho e certa desmobilização pelo fato de que "as determinações haviam chegado prontas de Brasília" não tendo ocorrido o envolvimento dos gestores em nenhuma discussão prévia sobre a criação da lei. Assim revelaram que não se sentiam estimulados a um maior envolvimento e uma leitura atenta à nova norma. Um ano mais tarde, evidenciou-se que os gestores adquiriram conhecimento da nova instrução, porém se queixam da falta de detalhamento principalmente para o sentido "amplo e vago", segundo eles, da expressão "promoção do desenvolvimento nacional sustentável”.

A segunda questão refere-se aos itens da Instrução Normativa que os entrevistados consideram aplicáveis imediatamente às obras públicas. A análise dessa questão revela que a pergunta exigiu dos gestores claro entendimento da norma para que pudessem prover uma resposta com sólidos fundamentos. Os aspectos apontados nas respostas foram soluções aparentemente simples que podem ser aplicáveis no curto prazo, como o uso de torneiras temporizadas, sistemas de captação da água da chuva e dispositivos de redução do consumo de energia elétrica. Um ano depois, não foi apresentada pelos gestores praticamente nenhuma inovação adotada em função da norma, excetuando-se medidas para impedir o aumento de consumo de energia.

$\mathrm{Na}$ terceira questão trata-se de conhecer dos respondentes se a Instrução Normativa N01/2010 é suficientemente detalhada para nortear o trabalho dos gestores. A análise dos 
A agenda ambiental pública: barreiras para a articulação entre critérios de sustentabilidade e as novas diretrizes da administração pública federal brasileira

relatos informa que, em sua totalidade, os gestores percebem a norma como insuficientemente detalhada, pois segundo eles, estes não estão preparados para a tarefa de definir o escopo dos itens que serão incluídos na obra, para a qual não foram devidamente orientados, o que, segundo os mesmos, acabará acarretando em aumento significativo do custo das obras. Essa percepção permaneceu na abordagem ocorrida um ano depois junto aos gestores e na avaliação dos mesmos, com a "agravante" do novo texto do art. $3^{\circ}$ da Lei $n^{\circ}$ 8.666/93 que exige a "licitação sustentável", o que, para os respondentes, é um termo muito abrangente e pouco claro.

A quarta questão investiga o impacto que as novas medidas gerarão nos custos diretos das obras. Nesse sentido, verificou-se que todos os entrevistados estão preocupados com os órgãos de controle, pois um item que possa ser considerado interessante por um gestor, poderá ser questionado por um dos inúmeros órgãos de controle como o Tribunal de Contas da União, a Controladoria Geral da União, o Tribunal de Contas da União, o Ministério Público Federal, a procuradoria do próprio INSS e auditoria interna. Um ano mais tarde a pesquisa registrou que aumentou a preocupação dos gestores com os custos acrescidos. Alguns revelaram que a lei tem colocado entraves à participação de empresas de pequeno porte que se apresentam como parceiras a serem contratadas as quais têm sido excluídas da categoria de licitação sustentável nas negociações por não apresentarem, conforme exigido por lei, certificações ambientais de seus serviços e materiais. Os gestores compreendem, todavia que essas implicações estavam previstas na instrução normativa.

$\mathrm{Na}$ quinta questão, tenta-se obter informação sobre a mensuração dos benefícios ambientais em longo prazo após inserir os critérios de sustentabilidade em obras públicas. A análise dessa questão na primeira fase do estudo revela que entre os sete gestores entrevistados, três não consideram possível mensurar os benefícios ambientais das medidas implantadas. Ocorre que a mensuração dos benefícios exige estudos de viabilidade e análise de custo-benefício e esse procedimento não é comum no trabalho destes gestores. A abordagem junto aos gestores um ano depois registra que a maioria dos entrevistados passou a considerar ser possível mensurar os benefícios ambientais das medidas implantadas, porém mediante estudos de viabilidade e análise de custo-benefício, uma atividade que passaram a incorporar, além de acompanhamento do histórico dos gastos com insumos numa instalação predial. Um gestor considerou a necessidade de um estudo multidisciplinar envolvendo uma equipe profissional capacitada para tal. 
A sexta questão, referente às principais dificuldades em operacionalizar a Instrução Normativa, a unanimidade dos gestores mostra-se preocupada com a fase licitatória, pois segundo os mesmos, determinadas exigências que garantiriam a sustentabilidade do empreendimento, como por exemplo, a comprovação de madeira certificada, entre outras, irão sugerir um direcionamento natural para as empresas certificadas que possuam estes procedimentos, o que implica em preços mais elevados. Pela Lei das Licitações, esta elevação de preços tem que ser justificada pelos gestores. Um ano depois, a pesquisa mostra que a unanimidade dos gestores permanece preocupada com a fase licitatória, pois as exigências podem ser consideradas pelos órgãos de controle como "avanços não paulatinos" e "desequilibrantes" das condições de isonomia de uma obra ou serviço. Permanece, portanto, por parte dos respondentes, o principal receio: os órgãos de controle. Segundo os gestores, os preços são padronizados pelo SINAP (base de dados de preços nacionais da Caixa Econômica Federal), e um item incomum que surja, deve apresentar uma análise de custo-benefício que por sua vez, precisa ser previamente aceita pela administração. Isso, segundo a maioria dos entrevistados, aumenta o trabalho, a burocracia e a responsabilidade dos técnicos e gestores, pois deve ser incorporado mais um tópico no escopo de um projeto.

A sétima questão que diz respeito às ações de sustentabilidade realizadas, na primeira etapa da pesquisa todos os gestores reconheciam que pouco ou quase nada havia sido incrementado para a inclusão dos critérios de sustentabilidade solicitados pela Instrução Normativa. Na segunda fase do estudo, ao serem mobilizados pela importância da sua contribuição para a continuidade da pesquisa, os gestores sugeriram a necessidade de adoção de gestão integrada para fazer valer a instrução normativa envolvendo ações de caráter multidisciplinar com a participação das várias áreas atuantes no INSS e não apenas a engenharia e a arquitetura.

$\mathrm{Na}$ oitava questão, identificaram-se as dificuldades apresentadas pelos gestores no tocante ao novo caráter da licitação implícita na nova legislação. Extraíram-se dos relatos que as dificuldades maiores parecem estar vinculadas ao princípio do menor preço, e também aos órgãos de controle que demandam a obrigatoriedade da análise de custo-benefício prévia de cada uma das medidas adotadas. Embora o novo caráter da licitação pressuponha a "licitação sustentável" o princípio do menor preço se configura, na visão dos entrevistados, como fator dificultador no edital de concorrência uma vez que empresas que oferecem certificações ambientais, que segundo os gestores, normalmente possuem uma estrutura administrativa maior, ofertarão preços maiores. 
A agenda ambiental pública: barreiras para a articulação entre critérios de sustentabilidade e as novas diretrizes da administração pública federal brasileira

$\mathrm{Na}$ nona questão, buscou-se conhecer outras medidas ou sugestões de mudança para efetivar a sustentabilidade desejada pela Instrução Normativa. A análise dos dados registrou que a maioria dos gestores não apresentou sugestões para acrescentar à norma na primeira etapa da pesquisa. Já na segunda etapa da pesquisa esse quadro começa a mudar: a maioria dos gestores sugere um maior detalhamento na legislação que seja compatível com as mudanças propostas na nova norma.

Na décima questão, indagou-se se há avanços percebidos, estimulados pela norma para a adequação do mercado. Os gestores percebem que as novas construções tendem a ter custos maiores e há a necessidade de justificá-los junto aos órgãos de controle e que caberá aos gestores executores, preparar antes de cada projeto uma análise de custo-benefício para cada medida de sustentabilidade adotada, valendo-se inicialmente de comparações de preços. As medidas poderão ser questionadas e os técnicos deverão preparar dossiês prévios para justificar cada medida, de forma que, ao se confrontar com os órgãos de controle ou o Judiciário, as memórias de cálculo estejam disponíveis e devidamente documentadas.

Os gestores acreditam que cada processo será eficaz em longo prazo para fazer valer o caráter de sustentabilidade da Instrução Normativa, conforme atesta um gestor: "quando todo o sistema se adequar, haverá benefício para o meio ambiente". Mesmo assim, a maioria dos entrevistados, depois de um ano de implementação da norma, permanece contestando a grande quantidade de justificativas a serem apresentadas aos diversos órgãos de controle e se dizem desestimulados a mudar ou inovar.

\section{CONSIDERAÇOES FINAIS}

A presente pesquisa teve como objetivo analisar a Instrução Normativa N01/2010 e suas implicações práticas como novo instrumento de política pública o qual determina condições para viabilizar a agenda ambiental da gestão pública. $\mathrm{Na}$ análise respondeu-se a questão de pesquisa no sentido de que foram identificados os fatores responsáveis pelo não alinhamento dos critérios de sustentabilidade ambiental exigidos à administração pública federal diante da situação em que se encontram as organizações parceiras contratadas, de modo a promover tal sustentabilidade. Esses fatores se constituem barreiras para efetivação da Instrução Normativa N01/2012 as quais são aqui discutidas.

Viu-se de um lado a necessidade de internalização e adequação da norma pelas obras da administração pública e seus principais desdobramentos com a modificação do art. $3^{\circ}$ da Lei de Licitação $n^{\circ} 8.666 / 93$ e por outro lado receios e resistência por parte daqueles que REAd I Porto Alegre - Edição 74 - № 1 - jan/abr 2013 - p. 139-164 
deverão por em prática no âmbito local, os projetos. A pesquisa revelou que as compras na administração pública, de materiais, obras e serviços, dentro dos novos padrões ambientais, num primeiro momento implicaram em maiores custos. Os gestores são normalmente pressionados a reduzir os custos dos projetos que gerenciam. Por isso na quarta questão, quando se quer saber dos gestores qual é o impacto que as medidas irão gerar nos custos diretos das obras, a maioria dos gestores sinalizou preocupações com justificativas que terão que apresentar junto aos órgãos de controle sobre o aumento direto dos custos das obras agora adicionado ao novo princípio da "promoção do desenvolvimento nacional sustentável", na percepção dos gestores termo aparentemente "vago" e "impreciso". Isso sugere que a Instrução Normativa N01/2010, apesar de emanada da esfera federal de governo poderá sofrer um bloqueio na esfera local de execução.

Um numeroso elenco de órgãos atuando junto aos assuntos relativos ao meio ambiente tanto legislando quanto fiscalizando ou orientando e controlando foi mostrado ao longo deste artigo. Isso torna o trabalho dos gestores extremamente complexo e pode desestimular a internalização do viés ambiental das novas obras públicas. A questão é, portanto, bastante intrincada, pois não há uma estrutura hierarquizada de controle como, a princípio, o Ministério do Meio Ambiente ou o IBAMA poderiam sinalizar; há uma crescente participação dos órgãos de controle, mesmo com atribuições sobrepostas. Isso se apresenta como de grande relevância para a pesquisa, visto que a nova ferramenta pressupõe a eficácia do arcabouço legal e regulatório voltado para as questões ambientais assim como traz à tona a questão da capacitação dos gestores públicos e privados para fazerem a norma funcionar.

Buscando a adoção de uma política de corresponsabilidade e de parceria através do diálogo, do convencimento e da conscientização da sociedade para a prática de uma gestão otimizada de seus recursos naturais, os órgãos de controle passaram a atuar mais ativamente sobre o planejamento das obras públicas, o que antes não ocorria. Exigências contidas na nova norma terão que ser cumpridas, porém se defrontam com a Lei no 8.666/93, reformulada, que determina o princípio do menor custo, mas também simultaneamente, a licitação sustentável, gerando um impasse.

No momento em que se percebe que os prejuízos ambientais podem ser contabilizados com o intuito de que estes sejam evitados ou minimizados, uma quantidade cada vez maior de técnicos auditores passará a atuar na questão, exigindo dos gestores públicos um aperfeiçoamento constante, uma atenção sem medidas aos seus procedimentos, um planejamento cada vez melhor das obras públicas dentro de critérios de sustentabilidade. 
A agenda ambiental pública: barreiras para a articulação entre critérios de sustentabilidade e as novas diretrizes da administração pública federal brasileira

Nesse sentido, o estudo recomenda que se investigue de modo comparativo a visão dos gestores e o desempenho das suas organizações de modo a se ter um panorama mais abrangente da problemática em questão.

O estudo sugere que os órgãos de certificação, fiscalização e controle ambientais devam ter uma atuação mais didática e pedagógica junto às organizações envolvidas e que essa atuação seja mais articulada de modo que se conheça com clareza as responsabilidades de cada uma. Sem a contribuição efetiva desses órgãos estará comprometida a sustentabilidade ambiental a que se propõe a nova agenda ambiental da gestão pública federal o que gerará incertezas quanto ao alinhamento da instrução normativa com a matriz dos mercados de serviços públicos ambientais.

Quadro 1 - Mapeamento Comparativo da Instrução Normativa N01/2010: Visão dos Gestores

\begin{tabular}{|c|c|c|c|c|c|c|c|c|}
\hline Gestores & Fase & Gestor 1 & Gestor 2 & Gestor 3 & Gestor 4 & Gestor 5 & Gestor 6 & Gestor 7 \\
\hline \multirow{2}{*}{$\begin{array}{l}\text { 1. Você tem } \\
\text { conhecimento } \\
\text { pleno da } \\
\text { legislação sobre } \\
\text { obras sustentáveis } \\
\text { e as premissas da } \\
\text { IN? }\end{array}$} & I & $\begin{array}{l}\text { Acabei de } \\
\text { conhecê-la. }\end{array}$ & Já conhecia. & $\begin{array}{l}\text { Acabei de } \\
\text { conhecê-la. }\end{array}$ & $\begin{array}{l}\text { Acabei de } \\
\text { conhecê-la. }\end{array}$ & $\begin{array}{l}\text { Conheço, porém } \\
\text { não sei como } \\
\text { aplicar. }\end{array}$ & $\begin{array}{l}\text { Acabei de } \\
\text { conhecê-la. }\end{array}$ & Acabei de conhecê-la. \\
\hline & II & $\begin{array}{l}\text { Tenho me } \\
\text { aprofundado no } \\
\text { assunto. }\end{array}$ & $\begin{array}{l}\text { Pude esclarecer } \\
\text { dúvidas. }\end{array}$ & $\begin{array}{l}\text { Pude esclarecer } \\
\text { dúvidas. }\end{array}$ & $\begin{array}{l}\text { Estou me } \\
\text { aprofundando } \\
\text { no assunto. }\end{array}$ & $\begin{array}{l}\text { Fomos } \\
\text { orientados a } \\
\text { como proceder. }\end{array}$ & $\begin{array}{l}\text { Estou me } \\
\text { aprofundando } \\
\text { no assunto. }\end{array}$ & $\begin{array}{l}\text { Estou me aprofundando no } \\
\text { assunto. }\end{array}$ \\
\hline \multirow[t]{2}{*}{$\begin{array}{l}\text { 2. Quais itens } \\
\text { você acha } \\
\text { aplicáveis } \\
\text { imediatamente às } \\
\text { obras públicas? }\end{array}$} & I & $\begin{array}{l}\text { Redução do } \\
\text { consumo de } \\
\text { energia elétrica } \\
\text { via tarifas. } \\
\end{array}$ & $\begin{array}{l}\text { A captação de } \\
\text { água da chuva } \\
\text { em obras novas. }\end{array}$ & $\begin{array}{l}\text { Equipamentos } \\
\text { temporizados, a } \\
\text { água da chuva e } \\
\text { maior eficiência. } \\
\end{array}$ & $\begin{array}{l}\text { A certificação } \\
\text { da madeira } \\
\text { utilizada nas } \\
\text { obras. }\end{array}$ & $\begin{array}{l}\text { Equipamentos } \\
\text { temporizados. }\end{array}$ & $\begin{array}{l}\text { Dispositivos } \\
\text { que } \\
\text { economizem } \\
\text { energia elétrica. }\end{array}$ & $\begin{array}{l}\text { Equipamentos } \\
\text { temporizados. }\end{array}$ \\
\hline & II & $\begin{array}{l}\text { Redução do } \\
\text { consumo de } \\
\text { energia. }\end{array}$ & $\begin{array}{l}\text { A captação de } \\
\text { água da chuva }\end{array}$ & $\begin{array}{l}\text { Equipamentos } \\
\text { temporizados. }\end{array}$ & $\begin{array}{l}\text { Atenção ao } \\
\text { descarte de } \\
\text { entulho. }\end{array}$ & $\begin{array}{l}\text { Equipamentos } \\
\text { temporizados. }\end{array}$ & $\begin{array}{l}\text { Redução do } \\
\text { consumo de } \\
\text { energia }\end{array}$ & $\begin{array}{l}\text { Equipamentos } \\
\text { temporizados. }\end{array}$ \\
\hline \multirow{2}{*}{$\begin{array}{l}\text { 3. A IN é } \\
\text { suficientemente } \\
\text { detalhada para seu } \\
\text { trabalho? }\end{array}$} & $\mathrm{I}$ & $\begin{array}{l}\text { Não, é bastante } \\
\text { incompleta. }\end{array}$ & $\begin{array}{l}\text { Não, é bastante } \\
\text { incompleta. }\end{array}$ & $\begin{array}{l}\text { Não, é bastante } \\
\text { incompleta. }\end{array}$ & $\begin{array}{l}\text { Sim, se só nos } \\
\text { atermos a ela. }\end{array}$ & $\begin{array}{l}\text { Não, é bastante } \\
\text { incompleta. }\end{array}$ & $\begin{array}{l}\text { Sim, se só nos } \\
\text { atermos a ela. }\end{array}$ & Não, é bastante incompleta. \\
\hline & II & $\begin{array}{l}\text { Com alterações } \\
\text { e acórdãos do } \\
\text { TCU. }\end{array}$ & $\begin{array}{l}\text { Está sendo } \\
\text { trabalhada. }\end{array}$ & $\begin{array}{l}\text { Está sendo } \\
\text { trabalhada. }\end{array}$ & $\begin{array}{l}\text { Sem } \\
\text { detalhamento, } \\
\text { ainda é geral. }\end{array}$ & $\begin{array}{l}\text { Está sendo } \\
\text { trabalhada. }\end{array}$ & $\begin{array}{l}\text { Órgãos como o } \\
\text { TCU tentam } \\
\text { disciplinar. }\end{array}$ & $\begin{array}{l}\text { Ainda faltam } \\
\text { complementos técnicos. }\end{array}$ \\
\hline \multirow{2}{*}{$\begin{array}{l}\text { 4. Qual o impacto } \\
\text { que as medidas } \\
\text { irão gerar nos } \\
\text { custos diretos das } \\
\text { obras? }\end{array}$} & I & $\begin{array}{l}\text { Aumento direto } \\
\text { do custo das } \\
\text { obras. }\end{array}$ & $\begin{array}{l}\text { Em médio prazo, } \\
\text { haverá economia. }\end{array}$ & $\begin{array}{l}\text { Aumento direto } \\
\text { do custo das } \\
\text { obras. }\end{array}$ & $\begin{array}{l}\text { Justificar os } \\
\text { aumentos de } \\
\text { custos. }\end{array}$ & $\begin{array}{l}\text { Certificações } \\
\text { gerarão maior } \\
\text { preço. }\end{array}$ & $\begin{array}{l}\text { Aumento direto } \\
\text { do custo das } \\
\text { obras. }\end{array}$ & $\begin{array}{l}\text { Estudos prévios de } \\
\text { economia em médio prazo. }\end{array}$ \\
\hline & II & $\begin{array}{l}\text { O custo tenderá } \\
\text { a aumentar. }\end{array}$ & $\begin{array}{l}\text { Em médio prazo, } \\
\text { haverá economia. }\end{array}$ & $\begin{array}{l}\text { O custo das } \\
\text { obras } \\
\text { aumentará. }\end{array}$ & $\begin{array}{l}\text { Problemas para } \\
\text { justificar os } \\
\text { aumentos de } \\
\text { custos. }\end{array}$ & $\begin{array}{l}\text { Empresas } \\
\text { certificadas } \\
\text { terão maior } \\
\text { preço. }\end{array}$ & $\begin{array}{l}\text { Aumento direto } \\
\text { dos custos das } \\
\text { obras. }\end{array}$ & $\begin{array}{l}\text { A introdução paulatina dos } \\
\text { critérios de } \\
\text { sustentabilidade. }\end{array}$ \\
\hline \multirow{2}{*}{$\begin{array}{l}\text { 5. Você consegue } \\
\text { mensurar os } \\
\text { benefícios } \\
\text { ambientais em } \\
\text { longo prazo em } \\
\text { obras públicas? }\end{array}$} & I & Sim. & Não. & Não. & $\begin{array}{l}\text { Analisando o } \\
\text { funcionamento } \\
\text { do prédio. }\end{array}$ & $\begin{array}{l}\text { Após a } \\
\text { amortização do } \\
\text { investimento. }\end{array}$ & Sim. & Não. \\
\hline & II & $\begin{array}{l}\text { Alguns são } \\
\text { muito difíceis } \\
\text { de mensurar. }\end{array}$ & Não. & Não. & $\begin{array}{l}\text { Só em médio } \\
\text { prazo. }\end{array}$ & $\begin{array}{l}\mathrm{Na} \text { amortização } \\
\text { do } \\
\text { investimento. }\end{array}$ & $\begin{array}{l}\text { Sim, numa } \\
\text { análise prévia. }\end{array}$ & Não. \\
\hline \multirow{2}{*}{$\begin{array}{l}\text { 6. Quais as } \\
\text { principais } \\
\text { dificuldades em } \\
\text { operacionalizar a } \\
\text { IN? }\end{array}$} & I & $\begin{array}{l}\text { O menor preço } \\
\text { estipulado pela } \\
\text { Lei } 8.666 / 93 \text {. }\end{array}$ & $\begin{array}{l}\text { O menor preço } \\
\text { estipulado pela } \\
\text { Lei } 8.666 / 93 \text {. }\end{array}$ & $\begin{array}{l}\text { Há dificuldades } \\
\text { de justificar tais } \\
\text { critérios. }\end{array}$ & $\begin{array}{l}\text { Estudos } \\
\text { prévios. }\end{array}$ & $\begin{array}{l}\text { Estudos prévios, } \\
\text { capacitação da } \\
\text { equipe técnica. }\end{array}$ & $\begin{array}{l}\text { O menor preço } \\
\text { estipulado pela } \\
\text { Lei } 8.666 / 93 \text {. }\end{array}$ & $\begin{array}{l}\text { O menor preço estipulado } \\
\text { pela Lei 8.666/93. }\end{array}$ \\
\hline & II & $\begin{array}{l}\text { Dificultou a } \\
\text { atuação dos } \\
\text { gestores e } \\
\text { técnicos. }\end{array}$ & $\begin{array}{l}\text { Dificultou a } \\
\text { atuação dos } \\
\text { gestores e } \\
\text { técnicos. }\end{array}$ & $\begin{array}{l}\text { Sim, a gestão } \\
\text { tem } \\
\text { dificuldades de } \\
\text { justificar tais } \\
\text { critérios. } \\
\end{array}$ & $\begin{array}{l}\text { As medidas } \\
\text { exigirão } \\
\text { estudos } \\
\text { prévios. }\end{array}$ & $\begin{array}{l}\text { Estudos prévios, } \\
\text { capacitação da } \\
\text { equipe técnica. }\end{array}$ & $\begin{array}{l}\text { Dificultou a } \\
\text { atuação dos } \\
\text { gestores e } \\
\text { técnicos. }\end{array}$ & $\begin{array}{l}\text { Dificultou a atuação dos } \\
\text { gestores e técnicos. }\end{array}$ \\
\hline \multirow{2}{*}{$\begin{array}{l}\text { 7. Quais ações de } \\
\text { sustentabilidade } \\
\text { vêm sendo } \\
\text { realizadas? }\end{array}$} & I & $\begin{array}{l}\text { Poucas, quase } \\
\text { nenhuma. }\end{array}$ & $\begin{array}{l}\text { Poucas, quase } \\
\text { nenhuma. }\end{array}$ & $\begin{array}{l}\text { Poucas, quase } \\
\text { nenhuma. }\end{array}$ & $\begin{array}{l}\text { Poucas, quase } \\
\text { nenhuma. }\end{array}$ & $\begin{array}{l}\text { Poucas, quase } \\
\text { nenhuma. }\end{array}$ & $\begin{array}{l}\text { Poucas, quase } \\
\text { nenhuma. }\end{array}$ & Poucas, quase nenhuma. \\
\hline & II & $\begin{array}{l}\text { Os critérios são } \\
\text { abrangentes } \\
\text { demais. }\end{array}$ & $\begin{array}{l}\text { Poucas, apesar da } \\
\text { Lei } 8.666 / 93 \text { ser } \\
\text { abrangente. }\end{array}$ & $\begin{array}{l}\text { Poucas, apesar } \\
\text { da Lei } 8.666 / 93 \\
\text { ser abrangente. }\end{array}$ & $\begin{array}{l}\text { Poucas, apesar } \\
\text { da abrangência } \\
\text { da Lei. }\end{array}$ & $\begin{array}{l}\text { É difícil falar } \\
\text { sobre critérios } \\
\text { tão gerais. }\end{array}$ & $\begin{array}{l}\text { Poucas, quase } \\
\text { nenhuma. }\end{array}$ & Poucas, quase nenhuma. \\
\hline
\end{tabular}


Maria Gracinda Carvalho Teixeira \& Luís Peres Azevedo

\begin{tabular}{|c|c|c|c|c|c|c|c|c|}
\hline \multirow{2}{*}{$\begin{array}{l}\text { 8. A que você } \\
\text { atribui as } \\
\text { dificuldades em } \\
\text { ação no tocante ao } \\
\text { novo caráter da } \\
\text { licitação? }\end{array}$} & I & $\begin{array}{l}\text { À Lei 8.666/93 } \\
\text { e aos órgãos de } \\
\text { controle. }\end{array}$ & $\begin{array}{l}\text { À Lei } 8.666 / 93, \\
\text { auditorias e } \\
\text { projetos. }\end{array}$ & $\begin{array}{l}\text { À Lei 8.666/93 } \\
\text { e aos órgãos de } \\
\text { controle. }\end{array}$ & $\begin{array}{l}\text { Às dificuldades } \\
\text { de projeto. }\end{array}$ & $\begin{array}{l}\text { À Lei 8.666/93 } \\
\text { e aos órgãos de } \\
\text { controle. }\end{array}$ & $\begin{array}{l}\text { Às dificuldades } \\
\text { de projeto. }\end{array}$ & $\begin{array}{l}\text { À Lei } 8.666 / 93 \text {, auditorias } \\
\text { e projetos. }\end{array}$ \\
\hline & II & $\begin{array}{l}\text { À Lei } 8.666 / 93 \\
\text { e aos órgãos de } \\
\text { controle. }\end{array}$ & $\begin{array}{l}\text { À Lei, aos órgãos } \\
\text { de controle e às } \\
\text { dificuldades de } \\
\text { projeto. }\end{array}$ & $\begin{array}{l}\text { À Lei 8.666/93 } \\
\text { e aos órgãos de } \\
\text { controle. }\end{array}$ & $\begin{array}{l}\text { Às dificuldades } \\
\text { de delimitar o } \\
\text { projeto. }\end{array}$ & $\begin{array}{l}\text { À Lei } 8.666 / 93 \\
\text { e aos órgãos de } \\
\text { controle. }\end{array}$ & $\begin{array}{l}\text { Às dificuldades } \\
\text { de delimitar o } \\
\text { projeto. }\end{array}$ & $\begin{array}{l}\text { À Lei, aos órgãos de } \\
\text { controle e às dificuldades } \\
\text { de projeto. }\end{array}$ \\
\hline \multirow{2}{*}{$\begin{array}{l}\text { 9. Você sugeriria } \\
\text { outras medidas ou } \\
\text { mudanças para } \\
\text { efetivar a } \\
\text { sustentabilidade } \\
\text { desejada pela } \\
\text { norma? }\end{array}$} & I & $\begin{array}{l}\text { A princípio são } \\
\text { suficientes. }\end{array}$ & Não. & Não. & Não. & Não. & Não. & Não. \\
\hline & II & $\begin{array}{l}\text { Melhor } \\
\text { detalhamento } \\
\text { dentro da Lei } \\
8.666 / 93 \text {. }\end{array}$ & $\begin{array}{l}\text { Melhor } \\
\text { detalhamento } \\
\text { dentro da Lei } \\
8.666 / 93 \text {. }\end{array}$ & $\begin{array}{l}\text { Sugeriria um } \\
\text { melhor } \\
\text { detalhamento. }\end{array}$ & Não. & Não. & Não. & $\begin{array}{l}\text { Sugeriria um melhor } \\
\text { detalhamento. }\end{array}$ \\
\hline \multirow{2}{*}{$\begin{array}{l}\text { 10. Há avanços } \\
\text { percebidos } \\
\text { estimulados pela } \\
\text { norma para a } \\
\text { adequação do } \\
\text { mercado? De que } \\
\text { forma? }\end{array}$} & I & $\begin{array}{l}\text { Sim, em longo } \\
\text { prazo. }\end{array}$ & $\begin{array}{l}\text { Sim, em longo } \\
\text { prazo. }\end{array}$ & $\begin{array}{l}\text { Sim, em longo } \\
\text { prazo. }\end{array}$ & $\begin{array}{l}\text { Sim, em longo } \\
\text { prazo. }\end{array}$ & $\begin{array}{l}\text { Sim, em longo } \\
\text { prazo. }\end{array}$ & $\begin{array}{l}\text { Sim, em longo } \\
\text { prazo. }\end{array}$ & Sim, em longo prazo. \\
\hline & II & $\begin{array}{l}\text { Sim, em } \\
\text { longo prazo. }\end{array}$ & $\begin{array}{l}\text { Sim, em longo } \\
\text { prazo. }\end{array}$ & $\begin{array}{l}\text { Sim, em } \\
\text { longo prazo. }\end{array}$ & $\begin{array}{l}\text { Sim, em } \\
\text { longo prazo. }\end{array}$ & $\begin{array}{l}\text { Sim, em } \\
\text { longo prazo. }\end{array}$ & $\begin{array}{l}\text { Sim, em } \\
\text { longo prazo. }\end{array}$ & Sim, em longo prazo. \\
\hline
\end{tabular}

Fonte: Elaboração própria com base nas entrevistas realizadas nas duas fases da pesquisa.

\section{REFERÊNCIAS}

ARCE, A., LONG, N. The dynamics of knowledge - interfaces between bureaucrats and peasants. In: ARCE, A., LONG, N. (Eds.). Battlefields of knowledge. London: Routledge, 1992, pp.58-99.

ARAÚJO, G. C. de, MENDONÇA, P. S. M. O processo de adequação à sustentabilidade empresarial a partir das normas internacionalmente reconhecidas. Encontro Internacional sobre Gestão Empresarial e Meio Ambiente, Curitiba. IX Anais Eletrônicos, pap0035, 2007.

BARBIERI, J. C. Gestão ambiental empresarial. São Paulo: Saraiva, 2007.

BIRDEMAN, R. et al. Guia de compras públicas sustentáveis: uso do poder de compra do governo para a promoção do desenvolvimento sustentável. Rio de Janeiro: FGV, 2006.

BRASIL/CONSTITUIÇÃO FEDERAL. Constituição Federal, 1988. Disponível em: http://www.planalto.gov.br/ccivil_03/Constituicao/Constituicao.htm. Acesso em 16 de maio de 2010 .

BRASIL/MMA - Ministério do Meio Ambiente. Agenda Ambiental na Administração Pública. Brasília: MMA/SDS/PNEA, 2001. 
A agenda ambiental pública: barreiras para a articulação entre critérios de sustentabilidade e as novas diretrizes da administração pública federal brasileira

BRASIL/MOPG - Ministério do Orçamento, Planejamento e Gestão. Instrução Normativa № 01 de 19 de janeiro de 2010, Brasília. Disponível em: http://www.comprasnet.gov.br. Acesso em 25 de janeiro de 2010.

CRUBELLATE, J. M. Três contribuições conceituais neofuncionalistas à teoria institucional

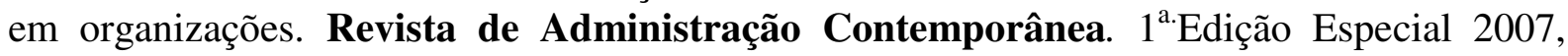
ANPAD, Curitiba, v. 11, n.1, pp. 199-222.

ENVIRONMENT CANADA. Acts., Regulations and Agreements. Disponível em: http://www.ec.gc.ca Acesso em 23 de outubro de 2012.

FARHAR, B., COBURN, T. A new market paradigm for zero-energy homes: a comparative case study. Environment Science and Policy for Sustainable Development. Philadelphia, 2008, January/February.Disponível em: http://www.environmentmagazine.org/Archives/Back Issues/January-February 2008/Farhar-abstract.html. Acesso em 13 de janeiro de 2011.

FED CENTER. Acquisition of Goods. Disponível em:

http://www.fedcenter.gov/programs/buygreen/ Acesso em 30 de outubro de 2012.

FERNANDES, J. U. J. Licitação Sustentável, 2010. Disponível em:

http://www.jacoby.pro.br/ManualdeContratosEcologicos.pdf. Acesso em 12 de fevereiro de 2010.

FEARNSIDE, P. M. Environmental services as a strategy for sustainable development in rural Amazonia. Ecological Economics. v. 20, 1997, pp. 53-70.

FERREIRA, F. S. dos. Licitação sustentável: a administração pública como consumidora consciente e diretiva. 2010. 136f. (Bacharelado em Direito) - Instituto de Ciências Sociais do Centro Universitário do Distrito Federal, Brasília.

GREEN BUILDING COUNCIL BRASIL. Green Buildings. Disponível em:

http://www.gbcbrasil.org.br/pt/index.php?pag=certificacao.php Acesso em 05 de fevereiro de 2011.

GIDDENS, A. The constitution of society: An outline of the theory of structuration. Cambridge: Polity Press, 1984. 
HEAL, G. Nature and the market place: Capturing the value of ecosystem services. Washington, DC: Island Press, 2000.

LIMA, L. H. M. de. O Tribunal de Contas da União e o controle externo da gestão ambiental. 2009. 365f. Rio de Janeiro: Tese. (Doutorado em Planejamento Ambiental) Programa de Planejamento Energético do Instituto Alberto Luiz Coimbra de Pós-Graduação e Pesquisa de Engenharia (COPPE), Universidade Federal do Rio de Janeiro, Rio de Janeiro.

NEPA - NATIONAL ENVIRONMENTAL POLICY ACT. The Environmental Quality Improvement Act of 1970, as amended (42 U.S.C. 4371 et seq.), sec. 309 of the Clean Air Act, as amended (42 U.S.C. 7609), and E.O.11514 (Mar. 5, 1970, as amended by E.O. 11991, May 24, 1977). Disponível em:

http://ceq.hss.doe.gov/ceq_regulations/Council_on_Environmental_Quality_Regulations.pdf em 31 de outubro de 2012.

NUNES, E. A gramática política do Brasil - clientelismo e insulamento burocrático. $3^{\mathrm{a}}$ ed. Jorge Zahar: Rio de Janeiro; ENAP: Brasília, 1997.

ORLANDI, E. P. Análise do discurso: princípios e procedimentos. Pontes: Campinas, 1999.

O'RIORDAN, T. On the politics of sustainability a long way ahead. Environment Science and Policy for Sustainable Development. Philadelphia, 2009, March/April. Disponível em: http://www.environmentmagazine.org/Archives/Back\%Issues/MarchApril\%2009/Bytesofnote /O’Riordan-html. Acesso em 13 de setembro de 2011.

PARRIS, T. M. Green Buildings. Environment Science and Policy for Sustainable Development. Philadelphia, 2007, January/February. Disponível em:

http://www.environmentmagazine.org/Archives/Back\%20Issues/JanuaryFebruary\%2007Byte sofnote/Parris-. html. Acesso em 15 de agosto de 2011.

PECI, A. A nova teoria institucional em estudos organizacionais: uma abordagem crítica. Cadernos EBAPE. FGV, v. 4 n.1, 2006, pp. 1-12.

PIMENTEL, C., ITANI, E., D’AMICO, V. Curso e-learning de licitações e contratações sustentáveis. 2010. São Paulo: FUNDAP - Fundação para o desenvolvimento Administrativo. Disponível em:

http://www.governoemrede.sp.gov.br/ead/lictsustentavel/saibamais/saibamais_modulo_01.pdf Acesso em 10 de março de 2011. 
A agenda ambiental pública: barreiras para a articulação entre critérios de sustentabilidade e as novas diretrizes da administração pública federal brasileira

SANTOS, F. V. dos. A legalidade das compras públicas sustentáveis. Jus Navigandi, Teresina, PI, Ano 16, n. 2774, 4 de fevereiro. 2011. Disponível em:

http://jus.uol.com.br/revista/texto/18421 Acesso em 10 de março de 2011.

SUSTAINABLE DEVELOPMENT IN GOVERNMENT. Government Buying Standards. Disponível em: http://sd.defra.gov.uk/advice/public/buying/ Acesso em 30 de agosto de 2012.

POWELL, I., WHITE, A. Conceptual framework - development markets and market-based instruments for environmental services of forests. Washington, DC. Forest Trends, 2001, Katoomba Group. Disponível em: http://www.forest-trends.org. Acesso em 07 de setembro de 2011.

SANTOS, L. W. M. A. A Auditoria de aspectos ambientais nas obras públicas, Rio de Janeiro: TCU, 2002.

SCOTT, W. R. The organizations of environments: networks, cultural and historical elements. In: MEYER, J. W., SCOTT, W. R. (Orgs.), Organizational environments: ritual and rationality. London: Sage, 1983.

TEIXEIRA, M. G. C., AZEVEDO, L. P. Política ambiental: uma abordagem analítica do desenho político-institucional para a sua instrumentalização na gestão ambiental empresarial no Brasil. RGSA - Revista de Gestão Social e Ambiental. Edição Especial, Set.-Dez. 2009. V. 3, No. 3, pp. 137154. Disponível em:

http://www.Revistargsa.org/ojs/index.php/rgsa/articles/viewFile/181/82. Acesso em 15 de janeiro de 2010.

VERGARA, S. C. Projetos e Relatórios de Pesquisa em Administração. São Paulo: Atlas, 2006.

VEIGA NETO, F. C., MAY, P. H. Mercado para serviços ambientais. In: MAY, P. (Org.) Economia do meio ambiente teoria e prática. Rio de Janeiro: Elsevier, 2010. 